Grażyna B. Szczygieł

\title{
Wykonywanie kary pozbawienia wolności w Polsce międzywojennej
}

Keywords: Prison penalty, progressive penitentiary system

\section{Summary}

The article is concentrated on the procedure of carrying out the prison penalty in 1918-1938. You can distinguish two periods important for Polish penitentiary law in these times. The first of them was marked by taking out prisons from the occupants' hands and by building grounds of Polish penitentiary system. The important step on this field was done on March 7th, 1928, when the President's decree on system of prison organization was passed. This decree opens new period in Polish penitentiary system, because the progressive system of carrying out the prison penalty was introduced to Polish law then. The model was in accordance with the European standards and was taking into account the resolutions of penitentiary congresses of this time. However, the reality of prisons was significantly different. The progressive system was introduced only with small group of sentenced persons. More than $70 \%$ of prisoners had no work and they were kept in crowded prisons with no sufficient hygienic conditions. The problem of crowded prisons was only partially solved by the amnesty acts.

I. Rozpoczęta po odzyskaniu niepodległości odbudowa struktur państwa polskiego objęła także więziennictwo. Przejmowanie zakładów karnych od zaborców rozpoczęto w 1918 r. Wprawdzie we wrześniu 1917 r. Niemcy i Austriacy przekazali sądownictwo władzom polskim, które były organem wykonawczym Tymczasowej Rady Stanu, a później Rady Regencyjnej, lecz nie przekazali zakładów karnych. Miało to nastąpić 1 września 1918 r. Termin ten jednak nie został dotrzymany. Następny termin wyznaczono na 1 października 1918 r., ale rokowania 
przedłużały się. Ilekroć zbliżał się termin wydania więzień Polakom - jak opisuje J. Zakrzewski' ${ }^{1}$ któremu powierzono całokształt czynności związanych z utworzeniem polskiego więziennictwa - „zostawał on z błahych powodów i zupełnie $\mathrm{z}$ więziennictwem niezwiązanych odraczany”. Po długich pertraktacjach więzienia w okupacji austriackiej przeszły pod zarząd władz polskich po 1 listopada, a w okupacji niemieckiej 11 i 12 listopada $1918 \mathrm{r}$. Więzienia w byłym zaborze austriackim przeszły pod zarząd Ministerstwa Sprawiedliwości w grudniu 1918 r., w byłej dzielnicy pruskiej zaś nastąpiło to dopiero 15 listopada 1922 r. Zarząd więzień w Wielkopolsce i na Pomorzu Ministerstwo Sprawiedliwości przejęło w listopadzie 1921 r. Także w listopadzie, ale w 1922 r. przejęto jednostki penitencjarne na terenie Górnego Śląska. W grudniu 1920 r., po likwidacji Zarządu Terenów Przyfrontowych i Etapowych przejęto więzienia na Kresach, a w kwietniu 1922 roku więzienia na Wileńszczyźnie ${ }^{2}$. Ogółem przejęto 400 jednostek penitencjarnych ${ }^{3}$. W następnych latach kilka jednostek zostało zlikwidowanych ze względu na ich zły stan. Ostatecznie pozostało 340 więzień i ta liczba utrzymywała się do $1939 \mathrm{r}^{4}$

Po przejęciu jednostek penitencjarnych władze polskie przystąpiły do uruchamiania więzień i zapewnienia ich właściwej działalności. Następowało to $\mathrm{w}$ trudnych warunkach. Przejęte więzienia były bowiem w bardzo złym stanie. W budynkach panowały fatalne warunki higieniczne. Tak opisywał przejęte od Austriaków więzienia Z. Bugajski: „Panował w więzieniach brud, pełno było robactwa, pluskiew, wszy, w wielu więzieniach panował tyfus, na tle głodowym szerzyła się gruźlica, więźniowie mieli opuchnięte nogi”’ Warsztaty pracy zostały zdemontowane, a wszystkie części okupanci zabrali lub zniszczyli6. Więźniowie byli wygłodzeni, zaborcy bowiem opuszczając więzienia nie zostawili zapasów żywności. Nie było także personelu więziennego.

J. Zakrzewski, Jak powstawało polskie więziennictwo, [w:] Księga Jubileuszowa. Więziennictwo Polskie 1918-1928, Warszawa 1929, s. 45.

2 Pierwsze pięciolecie więziennictwa w Polsce - przemówienie Dyrektora Departamentu Więziennego Jana Zakrzewskiego $w$ d. 11 listopada r. 1923, wygłoszone na akademii jubileuszowej pięciolecia więziennictwa, [w:] Księga Jubileuszowa. Więziennictwo Polskie 1918-1928..., s. 47-49; Z. Bugajski, Nowa organizacja więziennictwa polskiego w oświetleniu historycznym, Warszawa 1937, s. 20-22; Z. Bugajski, E. Neymark, Aktualne zagadnienia i projekty reformy więziennictwa, Warszawa 1925, s. 122; K. Pawlak, Więziennictwo Polskie w latach 1918-1939, Kalisz 1995, s. 8; M. Czerwiec, Więzienioznawstwo. Zarys rozwoju więziennictwa (Materiały na prawach rękopisu), Warszawa 1958, s. 209; J. Migdał, J. Raglewski, Kara pozbawienia wolności. Zarys dziejów polskiej doktryny penitencjarnej, Gdańsk 2005, s. 121.

${ }_{3}$ Z. Bugajski, E. Neymark, Aktualne zagadnienia i projekty reformy..., s. 229-230.

${ }^{4}$ K. Pawlak, Organizacja więziennictwa polskiego, [w:] Księga jubileuszowa więziennictwa polskiego 1918-1988, pod red. A. Marka, Warszawa 1990, s. 56.

${ }_{5}$ Z. Bugajski, Nowa organizacja więziennictwa polskiego..., s. 22. Zob. także M. Czerwiec, Więzienioznawstwo..., s. 210. J. Migdał, J. Raglewski, Kara pozbawienia wolności..., s. 123.

${ }_{6}$ Pierwsze pięciolecie więziennictwa polskiego - przemówienie Dyrektora Departamentu Więziennego..., s. 48. Zob. także H. Jankowski, Higiena więzień, [w:] Księga Jubileuszowa. Więziennictwo Polskie 1918-1928..., s. 101. 
Równocześnie rozpoczął się proces tworzenia podstaw prawnych polskiego systemu penitencjarnego. Po zaborcach odziedziczyliśmy nie tylko więzienia, ale również różne regulacje prawne dotyczące wykonywania kary pozbawienia wolności ${ }^{7}$, a także trzy ustawy karne. Na terenach byłego zaboru rosyjskiego obowiązywał kodeks rosyjski z 1903 r. i ustawa o więzieniach z 1890 r. oraz ustawa o zakładach wychowawczo-poprawczych dla nieletnich z 1909 r. Na ziemiach byłego zaboru pruskiego obowiązywał Kodeks karny Rzeszy Niemieckiej z 1871 r. i ordynacja więzienna zarządu sprawiedliwości z 1898 r., na obszarze byłego zaboru austriackiego Ustawa karna austriacka o zbrodniach, występkach i przekroczeniach z $1852 \mathrm{r}$. i ustawa postępowania karnego z $1873 \mathrm{r}$.

II. Pierwsze akty prawne dotyczące wykonywania kary pozbawienia wolności wydano w 1919 r. Był to Dekret Naczelnika Państwa z dnia 8 lutego 1919 r. w sprawie tymczasowych przepisów więziennych ${ }^{8}$ i Dekret Naczelnika Państwa z dnia 7 lutego w przedmiocie organizacji okręgowych dyrekcji więziennych ${ }^{9}$.

Wzorem państw ówczesnej Europy Zachodniej przyjęto koncepcję, iż celem wykonywania kary pozbawienia wolności jest poprawa więźnia ${ }^{10}$. Pracę uznano za jeden z podstawowych środków poprawczych, który miał na celu, jak twierdził Jan Jaxa-Maleszewski ${ }^{11}$, ówczesny Dyrektor Departamentu Karnego Ministerstwa Sprawiedliwości, „przezwyciężenie istniejącego u wielu przestępców wstrętu do pracowitego życia, wdrożenie ich i wyuczenie pewnej pracy rzemieślniczej, wreszcie - zapewnienie im tą drogą możności egzystencji po wyjściu z więzienia”. Zwracano także uwagę na ekonomiczny aspekt pracy więźniów, a mianowicie pokrycie $\mathrm{z}$ otrzymanych dochodów chociażby $\mathrm{w}$ części wydatków na utrzymanie więźniów ${ }^{12}$, co było szczególnie istotne dla młodego państwa, którego kondycja finansowa nie była najlepsza. Więźniów zatrudniano $\mathrm{w}$ warsztatach więziennych, natomiast wyroby przez nich wyprodukowane nie tylko użytkowano na potrzeby więziennictwa, dążąc do samowystarczalności, ale również sprzedawano na rynkach zagranicznych. Rolników i robotników bez fachowego wykształcenia, którzy stanowili znaczną część ówczesnej populacji więziennej, zatrudniano na roli. Każde więzienie miało kawałek własnej roli lub ogrodu, z których tanio można było czerpać aprowizację. Gospodarstwa rol-

7 J. Migdał, J. Raglewski, Kara pozbawienia wolności..., s. 131; K. Pawlak, Więziennictwo Polskie w latach 1918-1939..., s. 16; J. Zakrzewski, Jak powstawało polskie więziennictwo..., s. 46.

8 Dz. Praw Państwa Polskiego Nr 15, poz. 202.

9 Dz. Praw Państwa Polskiego Nr 14, poz. 173.

10 Pierwsze pięciolecie więziennictwa polskiego - przemówienie Dyrektora Departamentu Więziennego..., s. 50.

${ }_{11}$ J. Jaxa-Maleszewski, Rozwój więziennictwa polskiego, [w:] Księga Jubileuszowa. Więziennictwo Polskie 1918-1928..., s. 63.

12 Z. Bugajski, Praca więźniów, [w:] Księga Jubileuszowa. Więziennictwo Polskie 1918-1928..., s. 157. 
ne utrzymywały też inwentarz. Zważywszy, że wśród więźniów znajdowały się osoby o różnych zawodach, wykorzystywano ich umiejętności przy remontach budynków więziennych. W 1922 r. zatrudnionych było 39\% więźniów, co - jak podkreślał J. Zakrzewski ${ }^{13}$, ówczesny Dyrektor Departamentu Więziennictwa - nie było szczytem marzeń.

Poza zatrudnieniem więźniów uznano za celowe, jak wynika z dekretu w sprawie tymczasowych przepisów więziennych (art. 10), objęcie nauką wszystkich dorosłych analfabetów, a stanowili oni 40\% ogółu więźniów. Minimum nauczania szkolnego w stosunku do więźniów z krótkimi wyrokami sprowadzało się do nauczania religii, czytania, pisania i rachunków oraz do urządzania pogadanek mających na celu uświadamianie narodowe. W więzieniach przeznaczonych do odbywania kar ponad 3 lata zakres nauczania szkolnego był rozszerzony do poziomu programu szkół powszechnych.

Ważnym krokiem na drodze tworzenia polskiego systemu penitencjarnego było rozporządzenie Prezydenta Rzeczypospolitej z dnia 7 marca 1928 r. w sprawie organizacji więziennictwa ${ }^{14}$ oraz rozporządzenie wykonawcze Ministra Sprawiedliwości z 22 czerwca 1928 r. o wykonaniu rozporządzenia Prezydenta Rzeczypospolitej z dnia 27 marca 1928 r. w sprawie organizacji więziennictwa ${ }^{15}$. Na treść obu aktów istotny wpływ miały obrady Kongresu Penitencjarnego w Londynie, który odbył się w 1925 r. ${ }^{16}$, a na którym zalecano przeprowadzenie klasyfikacji więźniów w celu zapobiegania demoralizacji „lżejszych przestępców przez bardziej zepsutych"17. Należy też wskazać na rozporządzenie ministra sprawiedliwości z dnia 20 czerwca 1931 r. w sprawie regulaminu więziennego ${ }^{18}$. Był to bardzo obszerny akt zawierający 291 paragrafów, w których uszczegółowiono przepisy rozporządzenia w sprawie organizacji więziennictwa. Godzi się zauważyć, iż był to jedyny regulamin więzienny wydany w ciągu dwudziestolecia 1919-1939, a który od 1945 r., w nieco zmienionej i przystosowanej do nowych warunków postaci, służył więziennictwu w pierwszym dziesięcioleciu Polski Ludowej ${ }^{19}$.

Ustrój władz więziennych był dwustopniowy. Na czele każdego więzienia stał naczelnik, który podlegał ministrowi sprawiedliwości.

Więzienia podzielono na trzy klasy. Więzienia I klasy, których pojemność określono w rozporządzeniu (art. 4) na ponad 450 osób, były przeznaczone do

\footnotetext{
${ }^{13}$ Pierwsze pięciolecie więziennictwa polskiego - przemówienie Dyrektora Departamentu Więziennego..., s. 52.

${ }^{14}$ Dz. U. R. P. Nr 29, poz. 173.

${ }^{15}$ Dz. U. R. P. Nr 64, poz. 591.

${ }^{16}$ Szerzej na temat Kongresu i jego obrad oraz udziału w nim Polaków zob. J. Migdał, J. Raglewski, Kara pozbawienia wolności..., s. 127-128.

${ }_{17}$ F. Głowacki, IX Międzynarodowy Kongres Penitencjarny i wyniki udziału w nim przedstawicieli Polski (Londyn 1925), [w:] Księga Jubileuszowa. Więziennictwo Polskie 1918-1928..., s. 232

${ }^{18}$ Dz. U. R. P. Nr 71, poz. 577.

${ }^{19}$ S. Walczak, Prawo penitencjarne. Zarys systemu, Warszawa 1972, s. 162.
} 
odbywania kar dłuższych, a za takie uznano kary ponad 3 lata, więzienia II klasy o pojemności 150-450 osób były przeznaczone do odbywania kar od jednego roku do trzech lat, natomiast więzienia III klasy o pojemności do 150 osób do odbywania kar do jednego roku. Obok klasyfikacji więzień wprowadzono zasady segregacji więźniów. Kryteria segregacji to płeć, wiek, kategorie przestępstw, poziom intelektualny, recydywa. Dla nieletnich przestępców skazanych na karę bezwzględnego pozbawienia wolności, tj. bez zamiany na umieszczenie w zakładzie wychowawczo-poprawczym, utworzono przy sześciu więzieniach oddziały specjalne, co miało umożliwiać racjonalne oddziaływanie.

W 1928 r. w Polsce były 333 więzienia, w tym klasy I - 33, II klasy - 47, III klasy - 32, przy sądach grodzkich zaś - 221 więzień. Ogólna pojemność więzień wynosiła 36667 miejsc $^{20}$.

Po wejściu w życie kodeksu karnego z 1932 r. niezbędna okazała się modyfikacja dotychczasowej organizacji systemu więziennego. Kodeks karny bowiem wprowadził dwa rodzaje kary pozbawienia wolności, a mianowicie karę więzienia, która mogła trwać najmniej 6 miesięcy, a najwyżej 15 lat oraz karę więzienia dożywotniego. Drugi rodzaj kary pozbawienia wolności - areszt trwał najmniej tydzień, a najwyżej 5 lat.

Zarządzeniem ministra sprawiedliwości z dnia 3 sierpnia 1937 r. w sprawie podziału więzień ${ }^{21}$ zakłady karne podzielono na dwie kategorie, a mianowicie więzienia specjalne i więzienia zwykłe. Do więzień specjalnych kierowała Komisja do Badań Kryminologiczno-Biologicznych przy ministrze sprawiedliwości. Więzienia specjalne podzielono na dwa typy. Więzienia specjalne pierwszego typu były przeznaczone dla specjalnych kategorii więźniów, tj. dla recydywistów skazanych na kary więzienia przekraczające rok, przestępców zawodowych, z nawyknienia oraz dla tych, w stosunku do których stosowane dotychczas środki nie odniosły pożądanego skutku i mieli oni negatywny wpływ na innych więźniów. W tych więzieniach stosowano maksymalne środki zabezpieczenia. Drugi typ - to więzienia resocjalizacyjne. Kierowano do nich mężczyzn w wieku od 17 do 30 lat. Skazani ze środowiska wiejskiego byli kierowani do kolonii rolnych, a ze środowisk miejskich do więzień - zakładów rzemieślniczych. W więzieniach specjalnych wyodrębniono oddziały dla skazanych na karę dożywotniego więzienia oraz oddziały dla niepełnowartościowych psychicznie. Skazani, którzy nie zostali skierowani do więzień specjalnych, odbywali karę w zakładach zwykłych ${ }^{22}$. Więzienia zwykłe dzielono na pięć grup w zależności od wielkości

${ }^{20}$ S. Lelental, Rozwój ustawodawstwa i praktyka wykonywania kary pozbawienia wolności w okresie międzywojennym (1918-1939), [w:] Zagadnienia Prawa Karnego, Acta Universitatis Lodzienis, Folia Iuridica 47, Łódź 1991, s. 98.

${ }^{21}$ Dz. U. Nr 5, poz. 38.

${ }^{22}$ L. Radzinowicz, Penitencjarne kolonie rolnicze w Polsce, „Głos Sądownictwa” 1936, nr 7-8, s. 551; T. Krychowski, Polski system penitencjarny, „Przegląd Więziennictwa Polskiego” 1936, nr 1, s. 13-15. 
orzeczonej kary. Tworzono w nich oddziały dla nieletnich i przestępców przeciwpaństwowych. Skazanych po raz pierwszy na karę nieprzekraczającą rok pozbawienia wolności można było umieszczać $\mathrm{w}$ tzw. ruchomych ośrodkach pracy.

Wykonywanie kary pozbawienia wolności oparto na systemie progresywnym. System ten ówcześnie był uważany za najlepszy ${ }^{23}$. Zdaniem E. Krzymuskiego ${ }^{24}$ : „Daje on bowiem państwu, jak żaden inny, możność uczynienia z kary środka do osiągnięcia celów odstraszenia i poprawy, a oprócz tego każe troszczyć się o los, który czeka skazańca na wolności, i chce go wypuszczać z murów więzionych zdolnym do uczciwego zarabiania na życie”. Zarówno E. Krzymuski, jak i W. Makowski ${ }^{25}$, który również opowiadał się za systemem progresywnym, wskazywali na wysokie koszty wprowadzenia tego systemu. E. Krzymuski ${ }^{26}$ tak uzasadniał celowość poniesienia tych kosztów: „Sądzę jednak, że korzyści, wypływających z dobrej organizacji więzień, choćbyśmy mieli do nich zaliczyć tylko zmniejszenie się liczby recydywistów, państwo powinno uważać tę kwestyę za rzecz pierwszorzędnej wagi i nie usuwać się od jej pomyślnego załatwienia, dlatego tylko, że kosztowałoby to za drogo".

E. Neymark ${ }^{27}$ uznał wprowadzenie systemu progresywnego wykonywania kary za jedną z podstawowych reform naszego więziennictwa, która przy dobrej organizacji tego systemu "przyczyni się wydatnie do tego, aby kara pozbawienia wolności dawała istotnie dobre wyniki w kierunku poprawy przestępców".

Celem wykonywania kary pozbawienia wolności według systemu progresywnego, jak wynika z regulaminu więziennego ( $\$ 229)$, było stopniowe przygotowanie więźnia do normalnego trybu życia na wolności. W regulaminie wskazano na środki do osiągnięcia tego celu. Były to:

a) segregacja więźniów i osadzanie ich w różnych więzieniach, w zależności od cech indywidualnych, wieku, pobudek przestępstwa, poprzedniej karalności i czasu trwania kary;

b) podział na klasy - ze stopniowaniem polepszania warunków życia więziennego i rozszerzania zakresu ulg dla więźniów w zależności od stopnia wykazanej poprawy;

c) praca obowiązkowa, kształcenie ogólne i zawodowe oraz wychowanie moralne i religijne.

${ }^{23}$ J. Jaxa-Maleszewski, Rozwój więziennictwa polskiego, [w:] Księga Jubileuszowa. Więziennictwo Polskie 1918-1928..., s. 63; E. Krzymuski, Wykład prawa karnego ze stanowiska nauki i prawa austriackiego, wydanie trzecie przerobione, t. 1, Kraków 1911, s. 491.

${ }^{24}$ E. Krzymuski, Wykład prawa karnego ze stanowiska nauki i prawa austriackiego..., s. 491.

${ }^{25}$ W. Makowski, Prawo karne. Część ogólna. Wykład porównawczy prawa karnego austriackiego, niemieckiego i rosyjskiego obowiązującego w Polsce, Warszawa - Lublin - Łódź - Poznań - Kraków b.d.w., s. 350 .

${ }^{26}$ E. Krzymuski, Wykład prawa karnego ze stanowiska nauki i prawa austriackiego..., s. 491.

${ }^{27}$ E. Neymark, Zasady nowej organizacji więziennictwa w świetle nowoczesnych postulatów nauk penitencjarnych, [w:] Księga Jubileuszowa. Więziennictwo Polskie 1918-1928..., s. 204-205. 
Więźniowie odbywający karę w systemie progresywnym przechodzili przez trzy klasy. Przejście z jednej klasy do drugiej uzależnione było od stopnia wykazanej przez więźnia poprawy i powodowało stopniowe polepszanie warunków życia więziennego oraz rozszerzanie zakresu ulg. Zważywszy, że konsekwentne przeprowadzenie tego systemu wymagało pewnego czasu, ustalono, że będzie miał on zastosowanie do kar orzeczonych na czas ponad 3 lat.

Skazani rozpoczynali odbywanie kary w klasie pierwszej. Czas pobytu w tej klasie uzależniony był od kategorii więźnia. Recydywiści przebywali w niej co najmniej 12 miesięcy, w tym przez okres trzech pierwszych miesięcy w celi jednoosobowej. W przypadku innych więźniów minimalny okres pobytu w klasie pierwszej ustalono na sześć miesięcy. Pozostały do końca kary czas, po odliczeniu pobytu w pierwszej klasie oraz odliczeniu czasu trwania aresztu tymczasowego zaliczonego na poczet kary i trzeciej części kary orzeczonej przez sąd na późniejsze ewentualne przedterminowe zwolnienie, dzielono na dwa równe okresy (II i III klasa). O przejściu z klasy niższej do wyższej bądź degradacji decydowała liczba uzyskanych przez więźnia punktów. Awansowanie z pominięciem kolejności klas było zabronione, degradacja zaś z pominięciem kolejności klas mogła być zastosowana wyjątkowo. Punktowano przede wszystkim dobre zachowanie, pilność w nauce i pracy. Tygodniowo więzień mógł uzyskać 10 punktów ${ }^{28}$. Liczbę punktów niezbędną do awansu więźnia z klasy do klasy określono indywidualnie dla każdego więźnia, w zależności od minimalnego terminu ustalonego na czas jego pobytu w danej klasie. Punkty wystawiał naczelnik więzienia lub $\mathrm{z}$ jego upoważnienia pomocnik $\mathrm{w}$ dziale wychowawczym po porozumieniu się $\mathrm{z}$ kapelanem, nauczycielami i pozostałymi pomocnikami naczelnika więzienia. Więźniowie klasy trzeciej po otrzymaniu niezbędnej dla tej klasy liczby punktów i odbyciu 2/3 kary mogli zostać zakwalifikowani do przedterminowego zwolnienia. Więźniów, którzy nie wykazywali poprawy pozbawiano prawa odbywania kary w systemie progresywnym i przenoszono do więzienia izolacyjnego.

Więźniom klasy pierwszej nie przysługiwały żadne ulgi regulaminowe. Korzystali oni z uprawnień więźniów osadzonych w więzieniach zwykłych. Do tych uprawnień, jak wynika z regulaminu więziennego, należało utrzymywanie kontaktów ze światem poza murami więzienia w postaci widzeń i korespondencji. Więźniowie mogli być odwiedzani raz na miesiąc nie więcej niż przez trzy osoby, a czas trwania widzeń wynosił 15-20 minut. Odwiedziny odbywały się pod nadzorem funkcjonariusza. Więźniowie mieli prawo wysyłać jeden list i otrzymywać dwa listy na miesiąc. Byli odżywiani na koszt państwa, a za zezwoleniem naczelnika więzienia mogli otrzymywać z zewnątrz bądź kupować za pieniądze uzyskane za pracę lub zdeponowane dwa razy w miesiącu produkty wymienione

${ }^{28} \mathrm{~W}$ praktyce punktacji nie wprowadzono, zob. M. Czerwiec, Więzienioznawstwo. Zarys rozwoju więziennictwa..., s. 223. 
$\mathrm{w}$ regulaminie $\mathrm{e}^{29}$ oraz tytoń i papierosy, gdy otrzymali zezwolenie na palenie tytoniu. Ci, którzy nie pracowali na dziedzińcu lub w ogrodzie bądź poza obrębem więzienia korzystali codzienne z przechadzki po dziedzińcu więzienia.

Więźniowie klasy drugiej korzystali z niektórych ulg regulaminowych ${ }^{30}$. Ponadto otrzymywali zezwolenie na przyjmowanie odwiedzin raz na dwa tygodnie, wysyłanie i otrzymywanie jednego listu raz na dwa tygodnie oraz korzystanie z jednogodzinnej przechadzki.

Więźniowie umieszczeni w klasie trzeciej korzystali z wszelkich regulaminowych ulg ${ }^{31}$, mogli także przyjmować odwiedziny raz w tygodniu w pomieszczeniu bez siatki, wysyłać i otrzymywać jeden list tygodniowo, korzystać z dwugodzinnej przechadzki, z oświetlenia w celi do godz. 22.00, z dogodniejszych cel, lepszego ubrania i pożywienia, prenumerować gazety i czasopisma oraz kupować książki z funduszów złożonych do depozytu lub otrzymywanych za pracę. Więźniowie w klasie trzeciej mogli mieć dowolne uczesanie i zarost oraz korzystać z własnej odzieży, bielizny, obuwia i pościeli.

Więzienia izolacyjne przeznaczone były dla przestępców zawodowych, nałogowych, recydywistów i ukaranych dyscyplinarnie. W więzieniu izolacyjnym nie mogli być umieszczani duchowni, kobiety, skazani na areszt i więźniowie, którzy nie ukończyli 21 lat. W więzieniu izolacyjnym przewidziano dwustopniowy system progresywny. Przeniesienie z klasy pierwszej do drugiej mogło nastąpić po upływie co najmniej trzech miesięcy nienagannego zachowania się oraz pilności w nauce i pracy. Po upływie co najmniej dziewięciu miesięcy pobytu w klasie drugiej więźniowie, którzy zachowywali się nienagannie, wykazali się pilnością $\mathrm{w}$ pracy i nauce, mogli być przeniesieni w celu odbycia pozostałej części kary do więzienia zwykłego. Brak pilności w nauce i pracy, złe zachowanie powodowało

${ }^{29}$ Zgodnie z $\$ 129$ regulaminu były to: chleb, bułki, suchary, cukier, kawa, herbata, kakao, mleko, ser, słonina, masło, wędliny, owoce i jarzyny, czekolada w tabliczce.

${ }^{30} \mathrm{~W}$ regulaminie więziennym $(\$ 233)$ wskazano na następujące ulgi: „pochwała na osobności lub w obecności więźniów albo komitetu więziennego, możność otrzymania książek z poza biblioteki więziennej, pozwolenie na częstsze korzystanie z biblioteki więziennej, pozwolenie na otrzymywanie do cel kajetów, przyborów piśmiennych i podręczników, bezpłatne udzielanie pocztówek, papieru listowego, kopert, znaczków pocztowych, możność dopomagania rodzinie pieniędzmi zarobionymi w więzieniu, zwiększenie zarobku, nagradzanie za postępy w nauce - książkami, a za pilność w pracy - narzędziami rzemieślniczymi, zezwolenie na uczęszczanie na zorganizowane w więzieniu koncerty, przedstawienia teatralne, audycje radiowe i wyświetlanie obrazów, pozwolenie na palenie tytoniu”.

${ }^{31}$ Więźniowie korzystali z ulg przewidzianych dla więźniów z klasy drugiej, a ponadto z takich ulg jak: pozwolenie na przyjmowanie odwiedzin oraz pisanie i otrzymywanie listów w częstszych odstępach czasu, pozwolenie na przyjmowanie odwiedzających osób w pomieszczeniach bez siatki w obecności funkcjonariuszy więziennych, możność korzystania z dłuższego widzenia, zatrudnienie w bibliotece, pracą biurową lub w charakterze pomocnika nauczyciela w szkole, bezpłatne otrzymywanie tytoniu, pozwolenie na zakup artykułów żywnościowych za pieniądze złożone do depozytu lub otrzymane za pracę, dłuższe korzystanie ze światła, możność noszenia przy sobie i umieszczania w celi przedmiotów należących do zwykłego użytku osobistego, mianowania starszym celi lub pomocnikiem instruktora warsztatowego, przedstawienia do ułaskawienia, otrzymania zapomogi przy zwolnieniu. 
degradację do klasy pierwszej. W klasie pierwszej więźniowie byli umieszczani w celach jednoosobowych, nie korzystali z ulg i nagród przewidzianych regulaminem i z prawa komunikowania się listowego lub osobistego $\mathrm{z}$ rodziną przez trzy miesiące. Nie otrzymywali przesyłek żywnościowych, nie mogli kupować żywności za pieniądze złożone do depozytu lub otrzymane tytułem wynagrodzenia za pracę. W klasie drugiej więźniowie mogli się komunikować listownie i osobiście raz na dwa miesiące z rodziną, mogli kupować dodatkową żywność za zarobione pieniądze oraz korzystali z wielu $\mathrm{ulg}^{32}$.

Skazani na areszt odbywali karę w oddziałach specjalnie w tym celu wyznaczonych. Mogli używać własnej odzieży, bielizny, obuwia i pościeli oraz nosić dowolne uczesanie i zarost, a także odżywiać się na koszt własny lub kupować dodatkową żywność w "granicach umiarkowania”. Skazani ci mogli przyjmować i wysyłać jeden list na tydzień. Podczas przechadzki mogli chodzić w grupach do 5 osób. Nie musieli uzyskiwać zgody na palenie tytoniu, tak jak inni więźniowie. Zgodnie z kodeksem karnym z 1932 r. mieli prawo wyboru rodzaju pracy.

W przypadku duchownych odbywających karę pozbawienia wolności przewidziano odstępstwa od ogólnych zasad odbywania kary. Duchowni przebywali w celach jednoosobowych, oddzieleni od innych więźniów, uprawnieni byli do odprawiania mszy, ale wówczas w kaplicy nie mogli przebywać inni skazani. Korzystali z własnej odzieży i mogli odżywiać się na własny koszt. Nie mogli być zatrudniani przy pracach uwłaczających ich godności, np. przy robotach gospodarczych.

Zważywszy, iż za cel wykonywania kary pozbawienia wolności uznano poprawę więźnia, wskazano środki, które miały być wykorzystane przy prowadzeniu oddziaływań wychowawczych. Do tych środków zaliczono obowiązkową pracę, kształcenie ogólne i zawodowe oraz wychowanie moralne i religijne, działalność kulturalno-oświatową i wychowanie fizyczne.

Opieka duchowa polegała na umożliwieniu więźniom korzystania z nauk moralnych i pociechy religijnej. W więzieniach były odprawiane nabożeństwa, a w szkołach więziennych wykładano religię. Na nabożeństwach mogli być obecni wszyscy więźniowie, którzy wyrazili takie życzenie.

${ }^{32}$ Były to następujące ulgi ( $\$ 239$ pkt c regulaminu więziennego): „pochwała na osobności lub w obecności więźniów albo komitetu więziennego, możność otrzymania książek z poza biblioteki więziennej, pozwolenie na częstsze korzystanie z biblioteki więziennej, pozwolenie na otrzymywanie do cel kajetów, przyborów piśmiennych i podręczników, bezpłatne udzielanie pocztówek, papieru listowego, kopert, znaczków pocztowych, możność dopomagania rodzinie pieniędzmi zarobionemi w więzieniu, zwiększenie zarobku, nagradzanie za postępy w nauce - książkami, a za pilność w pracy - narzędziami rzemieślniczymi, zezwolenie na uczęszczanie na zorganizowane w więzieniu koncerty, przedstawienia teatralne, audycje radiowe i wyświetlanie obrazów, pozwolenie na palenie tytoniu, bezpłatne otrzymanie tytoniu, otrzymanie zapomogi przy zwolnieniu". 
Przez działalność kulturalno-oświatową, jak pisał Z. Bugajskii ${ }^{33}$, „rozumiano całokształt środków oświecających umysły więźniów, wytwarzających elastyczność władz umysłowych, zaszczepiających w ich duszy pojęcie etyki społecznej, zaznamiających $\mathrm{z}$ ideałami narodowemi i uzupełniających zakres wiadomości praktycznych i zawodowych, zwłaszcza z dziedziny rzemiosł i rolnictwa”.

Obowiązkowemu nauczaniu podlegali więźniowie nieletni i dorośli, skazani na karę pozbawienia wolności ponad 6 miesięcy, którzy nie przekroczyli 40 roku życia i nie posiadali świadectwa ukończenia 4 klasy szkoły podstawowej. W 1928 r. 90\% skazanych, podlegających przymusowemu nauczaniu, uczyło się. Pozostali więźniowie mogli się uczyć po otrzymaniu zezwolenia od naczelnika. Oświata pozaszkolna polegała na organizowaniu odczytów, pogadanek, kółek dokształcających oraz krzewieniu czytelnictwa. W więzieniach zakładano biblioteki w celu wyrobienia u skazanych zamiłowania do czytania. W 1928 r. utworzono Centralną Bibliotekę Departamentu Karnego Ministerstwa Sprawiedliwości, której zadaniem było dostarczanie poszczególnym więzieniom kompletów książek.

Zatrudnienie więźniów miało za cel przystosowanie ich do dalszego uczciwego życia w społeczeństwie przez wpajanie zamiłowania do pracy, nauczanie pożytecznego rzemiosła, odpowiedniego do wykonywania na wolności. Więźniowie podlegali obowiązkowi pracy. Obowiązek ten przewidziano w kodeksie karnym. W kodeksie przewidziano zatrudnianie więźniów także poza więzieniem, co zostało ocenione przez W. Woltera ${ }^{34}$ jako obostrzenie kary. Więźniów można było zatrudniać w warsztatach i zakładach przemysłowych więziennych i wynajmować jako siłę roboczą. Przy wyznaczaniu więźniom pracy należało uwzględnić rodzaj i termin kary, wiek, płeć, stan zdrowia, stopień wykształcenia ogólnego i zawodowego, inteligencję, dotychczasowe zajęcie na wolności i w więzieniu, zamierzoną pracę po opuszczeniu więzienia, jak również zamiłowanie do pewnego rodzaju pracy. Więźniom, którzy przed osadzeniem zajmowali się pracą naukową, naczelnik więzienia mógł zezwolić na dalsze kontynuowanie pracy, jeżeli nie powodowało to zakłócenia porządku lub zagrożenia ucieczką.

Wychowanie fizyczne miało na celu wyrobienie poczucia dyscypliny oraz zapobieganie przez ćwiczenia gimnastyczne i sportowe ujemnym wpływom pozbawienia wolności na stan zdrowia.

Więźniowie za naruszenie rygoru i porządku więziennego podlegali odpowiedzialności dyscyplinarnej. Karę wymierzał naczelnik zakładu karnego, uwzględniając stopień winy, okoliczności czynu i indywidualne cechy charakte-

${ }^{33}$ Z. Bugajski, Rozwój działalności kulturalno-oświatowej w więzieniach, jej zadania i obecna reorganizacja w Polsce, [w:] Księga Jubileuszowa. Więziennictwo Polskie 1918-1928..., s. 106.

${ }^{34}$ W. Wolter, Zarys systemu prawa karnego. Część ogólna, t. 2, Kraków 1934, s. 38. 
ru sprawcy przekroczenia. Regulamin więzienny zawierał bardzo rozbudowany katalog kar dyscyplinarnych ${ }^{35}$, począwszy od kary nagany aż do przeniesienia do więzienia izolacyjnego. Decyzję o ukaraniu więzień mógł zaskarżyć. Zażalenie więźnia dyrektor niezwłocznie przekazywał do rozpatrzenia prokuratorowi okręgowemu.

Za wzorowe sprawowanie, postępy i pilność w pracy oraz w nauce naczelnik mógł udzielić ulgi lub nagrody z katalogu nagród przewidzianych $\mathrm{w}$ regulaminie. Katalog nagród ${ }^{36}$ był równie rozbudowany jak katalog kar.

Zwieńczeniem prac nad wypracowaniem polskiego systemu postępowania ze skazanymi w izolacji penitencjarnej była ustawa z 26 lipca 1939 r. o organizacji więziennictwa ${ }^{37}$. Wybuch II wojny światowej uniemożliwił wprowadzenie w życie rozwiązań w niej zawartych.

III. Oceniając polski system penitencjarny okresu międzywojennego, należy podzielić pogląd S. Walczaka ${ }^{38}$, iż „uregulowania okresu międzywojennego w stosunku do więźniów kryminalnych w zasadzie nie odbiegały od ówczesnego stanu obowiązującego w innych krajach Europy”. Godny podkreślenia jest fakt, że uwzględniały one zalecenia kongresów penitencjarnych, które odbyły się w Londynie (1925), Pradze (1930) i Berlinie (1935).

Ocena jednak nie byłaby pełna, gdyby pominięto warunki, w jakich model zakreślony przepisami był realizowany.

Jak już wspomniano na wstępie, przejęte od zaborców jednostki penitencjarne były w bardzo złym stanie. W następnych latach ich stan się nie poprawił.

Nie znamy dokładnej liczby osadzonych w pierwszym okresie po odzyskaniu niepodległości, a więc w latach 1918-1921. K. Pawlak ${ }^{39}$, powołując się na S. Cara, podaje, iż liczba więźniów wahała się w granicach od 33 do 44 tysięcy. Zważywszy, że więzienia były przeludnione, próbowano ten problem rozwią-

${ }^{35}$ Zgodnie z regulaminem więziennym ( $\left.\$ 165\right)$ były to: „nagana, pozbawienie ulg, pozbawienie prawa korzystania z książek na czas do dwóch tygodni, pozbawienie najwyżej 4-krotnie prawa komunikowania się osobistego i listowego z rodziną - na przeciąg nie dłuższy niż ogółem ponad 3 miesiące, pozbawienie prawa otrzymywania przesyłek żywnościowych na czas do 4-ch tygodni, pozbawienie prawa rozporządzania zarobkiem na przeciąg 4-ch tygodni, pozbawienie pracy zarobkowej na czas do 2 tygodni, zmniejszenie racji żywnościowej na czas do 2 tygodni, post o chlebie i wodzie w dniach przez inne przegrodzonych (ogólna liczba dni postu, wymierzonych jednorazowo, nie mogła przekraczać 7 dni), pozbawienie pościeli (twarde łoże) na czas do 1 tygodnia, samotne zamknięcie w jednoosobowej celi, na to przeznaczonej na czas do 2 tygodni; zamknięcie w ciemnej celi na czas do 48 godzin, degradacja do klasy niższej, przeniesienie do więzienia izolacyjnego".

${ }^{36}$ Zob. nagrody wymienione w przypisach 30 i 32 .

${ }^{37}$ Dz. U. Nr 68, poz. 457, 1939 r.

${ }^{38}$ S. Walczak, Początki więziennictwa polskiego, [w:] Księga jubileuszowa więziennictwa polskiego $1918-1988 \ldots$, s. 44.

${ }^{39}$ K. Pawlak, Więziennictwo Polskie w latach 1918-1939..., s. 50. 
zać przez amnestie. W latach 1919-1921 wydano dwie amnestie zasadnicze ${ }^{40}$ i 12 cząstkowych ${ }^{41}$, co spowodowało spadek liczby uwięzionych do 28388 w $1922 \mathrm{r}$.

Tabela 1. Liczba więźniów w latach 1922-193942

\begin{tabular}{|l|c|c|c|}
\hline Rok & $\begin{array}{c}\text { Liczba } \\
\text { więźniów }\end{array}$ & $\begin{array}{c}\text { Wskaźnik } \\
\text { wzrostu }\end{array}$ & $\begin{array}{c}\text { Zaludnienie } \\
\text { więzień (\%) }\end{array}$ \\
\hline 1922 & 28488 & 100,00 & 89 \\
\hline $1923^{*}$ & 26326 & 92,41 & 89 \\
\hline 1924 & 30947 & 108,63 & b. d. \\
\hline 1925 & 32085 & 112,62 & 76 \\
\hline 1926 & 30454 & 106,90 & 73 \\
\hline 1927 & 27625 & 96,97 & 67 \\
\hline $1928^{\star}$ & 29796 & 104,59 & 73 \\
\hline 1929 & 25073 & 88,01 & 72 \\
\hline 1930 & 30219 & 106,08 & 86 \\
\hline 1931 & 36130 & 126,83 & 100 \\
\hline $1932^{*}$ & 37982 & 133,32 & 98 \\
\hline 1933 & 34648 & 121,62 & 89 \\
\hline 1934 & 48444 & 170,05 & 123 \\
\hline 1935 & 55336 & 194,24 & b. d. \\
\hline $1936^{*}$ & 55336 & 194,24 & b. d. \\
\hline 1937 & 59496 & 208,84 & 143 \\
\hline 1938 & 68008 & 238,73 & 164 \\
\hline $193 *^{*}$ & 71316 & 250,33 & 140 \\
\hline$* a m n+13$ & & \\
\hline
\end{tabular}

*amnestie

Amnestia z $1923 \mathrm{r}^{43}$ także wpłynęła na zmniejszenie populacji więziennej, ale tylko w roku jej wydania. W kolejnych dwóch latach liczba więźniów istotnie się zwiększyła. W 1926 r. było o 4000 więźniów więcej niż w 1923 r. W więzieniach dochodziło do głodówek i protestów. W wyniku protestów Międzynarodowego Czerwonego Krzyża sejm powołał komisję do zbadania stosunków w więzieniach. Komisja po wizytacjach więzień w latach 1924-1925 stwierdziła

${ }^{40}$ Dekret z dnia 8 lutego 1919 r. Amnestia, Dz. Praw P. P. Nr 16, poz. 219; Ustawa z dnia 24 maja 1921 r. w przedmiocie amnestii z powodu uchwalenia ustawy Konstytucji Rzeczypospolitej Polskiej z dnia 17 marca 1921 r., Dz. U. Nr 24, poz. 261.

${ }^{41}$ K. Pawlak, Więziennictwo Polskie w latach 1918-1939..., s. 50.

${ }^{42}$ Dane dotyczące liczby więźniów pochodzą z opracowania S. Lelentala, Rozwój ustawodawstwa i praktyka wykonywania kary pozbawienia wolności w okresie międzywojennym (1918-1939)..., s. 99. Dane dotyczące zaludnienia więzień podaję za: K. Pawlak, Więziennictwo Polskie w latach 1918-1939..., s. 51. Wskaźnik wzrostu - obliczenia własne.

${ }^{43}$ Ustawa z dnia 6 lipca 1923 r. w przedmiocie amnestii z powodu uznania granic Rzeczypospolitej, Dz. U. Nr 71, poz. 555. 
przeludnienie więzień, bezrobocie, nieprzestrzeganie norm żywieniowych, elementarnych zasad higieny ${ }^{44}$. Następne lata, jeżeli chodzi o warunki panujące w więzieniach, nie przyniosły istotnych zmian. Nadal także systematycznie wzrastało bezrobocie wśród więźniów. Ponad 80\% więźniów, jak pisał L. Radzinowicz ${ }^{45}$, „tkwiło w bezczynności”, podczas gdy w 1922 r. pracowało 39\% więźniów.

W 1925 r. w jednostkach penitencjarnych przebywało 32085 więźniów. W latach następnych (1926-1927) nastąpił dość duży spadek populacji więziennej. Ta tendencja załamała się w 1928 r. Wydana w tym roku amnestia ${ }^{46}$ miała wpływ na zmniejszenie liczby więźniów, jednak tylko w następnym roku.

Jak zauważa K. Pawlak ${ }^{47}$, innym sposobem na zmniejszanie liczby więźniów było wykorzystanie instytucji warunkowego zwolnienia. W 1927 r. rozporządzeniem Prezydenta Rzeczypospolitej z dnia 18 stycznia o zwolnieniu przedterminowem osób odbywających karę pozbawienia wolności ${ }^{48}$ ujednolicono zasady zwolnienia. Zgodnie $z$ art. 1 rozporządzenia skazani na karę pozbawienia wolności mogli zostać przedterminowo zwolnieni, jeżeli odbyli dwie trzecie, najmniej jednak sześć miesięcy wymierzonej kary i przez ten czas prowadzili się dobrze. Do kary wymierzonej i odbytej nie wliczano zaliczonego na poczet kary aresztu zapobiegawczego. W latach 1927-1928 zwolniono 5090 skazanych $^{49}$.

Mimo tych zabiegów od 1929 r. systematycznie rosła liczba więźniów. Ta tendencja utrzymywała się do 1932 r. W tym roku w jednostkach penitencjar-

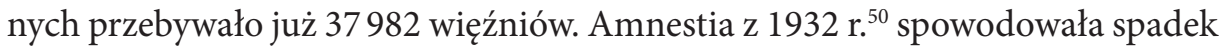
liczby więźniów do 34648 w 1933 r., ale już w następnym roku liczba więźniów wzrosła o około 14000, co spowodowało znaczny wzrost przeludnienia jednostek penitencjarnych. W latach 1935 i 1936 w więzieniach było 55336 osób. Wzrost liczby więźniów w latach trzydziestych był wynikiem wzrostu liczby przestępstw (prawie dwukrotny), co łączono z kryzysem i masowym bezrobociem ${ }^{51}$.

44 Szerzej omawia sprawozdanie komisji powołanej do badania stosunków w więzieniach z czynności dokonanych w 1924 r. i 1925 r. S. Walczak, Prawo penitencjarne..., s. 165. Zob. także tego autora: Początki i rozwój więziennictwa polskiego, [w:] Księga jubileuszowa więziennictwa polskiego 1918-1988..., s. 44-45.

${ }^{45}$ L. Radzinowicz, Kryzys polskiego ustroju penitencjarnego, „Gazeta Sądowa Warszawska” 1935, nr 24, s. 578.

${ }^{46}$ Ustawa z dnia 22 czerwca 1928 r. o amnestii z powodu odzyskania niepodległości przez Państwo Polskie, Dz. U. Nr 70, poz. 641.

${ }^{47}$ K. Pawlak, Więziennictwo Polskie w latach 1918-1939..., s. 54.

${ }^{48}$ Dz. U. R. P. Nr 5, poz. 25.

${ }^{49}$ K. Pawlak, Więziennictwo Polskie w latach 1918-1939..., s. 55.

${ }^{50}$ Rozporządzenie Prezydenta Rzeczypospolitej z dnia 21 października 1932 r. o amnestii z powodu wprowadzenia z dniem 1 września 1932 r. jednolitego polskiego kodeksu karnego i prawa o wykroczeniach, Dz. U. Nr 91, poz. 782.

${ }^{51}$ L. Radzinowicz, Kryzys polskiego ustroju penitencjarnego, „Gazeta Sądowa Warszawska” 1935, nr 4; T. Krychowski, Polski system penitencjarny..., s. 15. 
Zdaniem S. Lelentala ${ }^{52}$ „Dane statystyczne z lat 1935 i 1936 nie są w zupełności miarodajne, gdyż w marcu 1934 r. Minister Sprawiedliwości ze względu na przeludnienie więzień wstrzymał wykonywanie kar krótkoterminowych. Pomimo, że zarządzenie to obowiązywało w ciągu roku 1934 i z pewnymi modyfikacjami przez rok 1935 liczba więźniów systematycznie wzrastała. W końcu listopada 1935 r. Minister Sprawiedliwości ponownie zarządził zakaz osadzania w więzieniach skazanych na kary krótkoterminowe, co zmniejszyło zaludnienie więzień”.

Także amnestia z $1936 \mathrm{r} .{ }^{53}$ nie wpłynęła na wielkość populacji uwięzionych Od 1934 r. systematycznie wzrastała liczba więźniów. Gdy jeszcze w 1933 r. w jednostkach penitencjarnych było 34648 więźniów, to w 1939 r. liczba ta wynosiła 71316. W efekcie tak znacznego wzrostu populacji więzionych Polska w latach trzydziestych miała jeden $\mathrm{z}$ najwyższych współczynników osób uwięzionych na 100000 mieszkańcom ${ }^{54}$. W 1934 r. pojemność więzień została przekroczona o $123 \%$ i wskaźnik ten w następnych latach systematycznie rósł aż do $140 \%$ w $1939 \mathrm{r}^{55}$

Wzrostowi liczby więźniów nie towarzyszył wzrost pracowników służby więziennej. Z danych przedstawionych przez S. Pawlaka ${ }^{56}$ wynika, że w latach 1930-1934 liczba więźniów wzrosła o 60\%, natomiast liczba strażników o 12\%. Na jednego strażnika przypadało 13,4 więźnia, a 1938 r. - 16,1. Takie relacje nie pozostawały bez wpływu na prowadzenie oddziaływań wychowawczych.

Trafnie charakteryzował ówczesną rzeczywistość penitencjarną L. Radzinowicz $^{57}$ pisząc, iż „Mało jest krajów, w których dysproporcja pomiędzy tym co jest, a tym co powinno być, jest tak wielka, jak u nas".

${ }^{52}$ S. Lelental, Rozwój ustawodawstwa i praktyka wykonywania kary pozbawienia wolności w okresie międzywojennym (1918-1939)..., s. 98.

${ }_{53}$ Dekret Prezydenta Rzeczypospolitej Polskiej z dnia 2 września 1939 r. o amnestii, Dz. U. Nr 87, poz. 553.

${ }^{54}$ M. Melezini, Punitywność wymiaru sprawiedliwości karnej w Polsce w XX wieku, Białystok 2003, s. 316.

${ }^{55}$ Zob. K. Pawlak, Więziennictwo Polskie w latach 1918-1939..., s. 51.

${ }^{56}$ Ibidem, s. 29.

${ }^{57}$ L. Radzinowicz, Kryzys polskiego ustroju penitencjarnego..., s. 575; S. Walczak, Prawo penitencjarne..., s. 164. 